\title{
ひび割れを有するコンクリート中の 塩化物イオン移動評価手法の提案
}

\author{
塚原絵万 $^{1} \cdot$ 加藤佳孝 $^{2} \cdot$ 魚本健人 $^{3}$ \\ ${ }^{1}$ 正会員 博士（工）東京大学大学院 工学系研究科社会基盤工学専攻（テ $153-8505$ 目黒区駒場 4-6-1) \\ （(現）独立行政法人 港湾空港技術研究所（广239-0826 横須賀市長瀬 3-1 - 1)） \\ ${ }^{2}$ 正会員 博士 (工) 東京大学 生産技術研究所 講師（广153-8505 目黒区駒場 4-6-1) \\ 3 フェロー会員 工学博士 東京大学 生産技術研究所 教授（T153-8505 目黒区駒場 4-6-1)
}

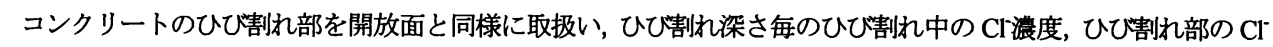
量, および $\mathrm{Cl}$ 量に対する質量保存則を考慮することにより，コンクリート中における濃度拡散と擬似吸着をマク 口的に表現した Cl移動評価モデルを構筑した. 提案モデルは，湿潤および乾湿繰返し環境下におけるひひ割れを 有するコンクリート試験体のCl濃度分布を精度良く評価することが可能であった．また，ひひ割れ幅およびひび 割れ中の見かけの Cl拡散係数がコンクリート中の Cl移動に及ぼす影響について検討を行った.

Key Words: chloride ion, crack, diffusion, boundary chloride content

\section{1. はじめに}

一般に，鉄筋コンクリート構造物はかぶりによっ て塩化物イオン, 酸素および水分等腐食因子の侵入 を抑制している. しかし，コンクリートにひび割れ が存在する場合, それらの物質は鉄筋まで容易に達 するため, 早期に鉄筋腐食が生じることとなり, 鉄 筋の付着力の堿退, 鉄筋断面積の減少等を引き起こ す.したがって, 構造物は期待される供用年数内に その性能を喪失することとなる．既往の研究によれ ば 1), 2)，表面ひび割れを有するコンクリートのひび 割れ部鉄筋の腐食形態はマクロセル腐食となること が多く，局部腐食を誘発する危険性があることが指 摘されている.このように, ひび割れが構造物の耐 久性能に与える影響が多大であることは認識されて いるが，ひび割れを有するコンクリート中の物質移 動に関しては，定量的な評価がなされていないのが 現状である.

本研究では，ひび割れを有するコンクリート中の 塩化物イオン移動性状を把握することを第 1 の目的 とした. そして, 得られた情報に基づいて, 移動評
価におけるひび割れの取扱い方法を提案し、ひび割 れを有するコンクリート中の塩化物イオン移動モデ ルを構築した.

\section{2. ひび割れを有するコンクリート中の塩化物 イオン移動性状}

\section{(1) 実験概要}

セメントは普通ポルトランドセメント, 細骨材は 富士川産川砂(表乾密度: $2.63 \mathrm{~g} / \mathrm{cm}^{3}$, 吸水率: $2.60 \%$, F.M. 2.81), 粗骨材は両神産砕石(表乾密度: $2.69 \mathrm{~g} / \mathrm{cm}^{3}$, 吸水率: 0.96\%, F.M. 6.70)を用いた。 なお，セメント 中に含まれる $\mathrm{Cl}$ は $0.010 \%$ (平均) である．表- 1 に コンクリートの配合および諸性質を示す.

試験体概要を図- 1 に示す. $70 \times 120 \times 380 \mathrm{~mm}$ の型 枠にコンクリートを打設し, 24 時間後脱型して材齢 28 日まで $20^{\circ} \mathrm{C}$ 水中養生を行った. 鉄筇はかぶり $30,60,90 \mathrm{~mm}$ となるよう試験体の中心に配置した. 養 生後, 2 点支持 2 点載荷により試験体下面に曲げひ び割れを設けた．除荷後，開口面におけるひび割れ 幅をマイクロスコープにより, 試験体両側面より目 
表-1 コンクリートの配合および諸性質

\begin{tabular}{|c|c|c|c|c|c|c|c|c|c|c|}
\hline \multirow{2}{*}{ Gmax } & \multirow{2}{*}{$\mathrm{W} / \mathrm{C}$} & \multirow{2}{*}{$\mathrm{s} / \mathrm{a}$} & \multicolumn{5}{|c|}{ 単位量 $\left(\mathrm{kg} / \mathrm{m}^{3}\right)$} & \multirow{2}{*}{$\begin{array}{c}\text { 空気量 } \\
\%\end{array}$} & \multirow{2}{*}{$\begin{array}{c}\text { スランオ } \\
\mathrm{cm}\end{array}$} & \multirow{2}{*}{$\begin{array}{c}f_{28} \\
N / m^{2}\end{array}$} \\
\hline & & & W & C & $S$ & G & SP & & & \\
\hline 20 & 0.39 & 0.420 & 177 & 454 & 720 & 1016 & 4.99 & 5.4 & 20 & 57.4 \\
\hline 20 & 0.55 & 0.463 & 167 & 304 & 857 & $\overline{1016}$ & 2.43 & 3.6 & 11 & 41.0 \\
\hline
\end{tabular}

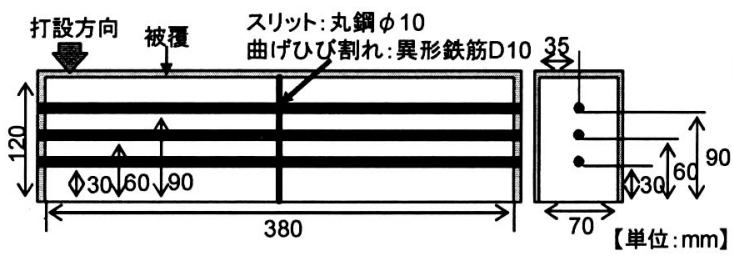

図- 1 試験体概要

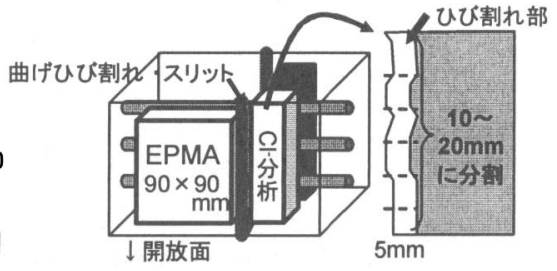

図-2 分析試料の採取
視範囲内のひび割れ深さを測定した. その後, ひび 割れ開口面（以降, 開放面と呼ぶ）を除く 5 面をエ ポキシ系樹脂により被覆し, $\mathrm{Cl}^{-}$が 1 面のみから侵入 するようにした．鉄筋両端部は自己癒着テープを用 いて被覆し，端部からの $\mathrm{Cl}$ の侵入を防いだ．なお， ひび割れ幅は開放面におけるひび割れ幅 7 点の平均 值である.

また，中央に 1 本スリットを設けた試験体を同時 に作成した. 型枠にかぶり 30,60,90mm となるよう丸 鋼（直径 $10 \mathrm{~mm}$ ）を配置した後, 鉄筋位置に孔（直 径 $10.2 \mathrm{~mm}$ ）を開けた鋼板を設置し，上面よりコンク リートを打設した。 なお, 養生後と試験終了後にス リット幅を測定した結果，スリット幅は打設時と変 わらず $0.20 \mathrm{~mm}$ 一定であった. その他, 養生, 被覆 等は曲げひび割れを有する試験体と同様である.

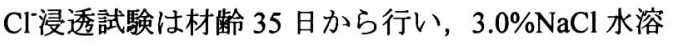
液浸漬試験, また, 1 日間の $3.0 \% \mathrm{NaCl}$ 水溶液浸漬お よび 6 日間の乾燥（相対湿度 60\%）を 1 サイクルと する乾湿繰返し試験を,それぞれ 13 サイクルまで行 った. $\mathrm{NaCl}$ 水溶液の温度, 乾燥時の環境温度は常時 $40^{\circ} \mathrm{C}$ 一定となるよう設定した.

試験終了後, ひび割れ部およびスリット部の $\mathrm{Cl}^{-}$ 量の測定と, EPMA を用いた $\mathrm{Cl}$ 分析を行った. 測定 試料は, 試験体より鉄筋を取り除いた後, 図- 2 に示 すようにひび割れ周辺部をカッターで切り出して作 成した。ここで, 本研究では, ひび割れ，またはス リットより垂直方向 0〜 $5 \mathrm{~mm}$ の範囲を「ひび割れ部」 として定義する.これは, 平均骨材粒径より考えら れるひび割れ表面の凹凸を考虑して設定した範囲で

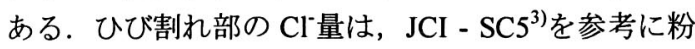
体試料から測定試料を作成し，塩分分析計により把 握した.また, EPMA 試料については, 測定面を鏡 面研磨し炭素蒸着を行って測定に供した.

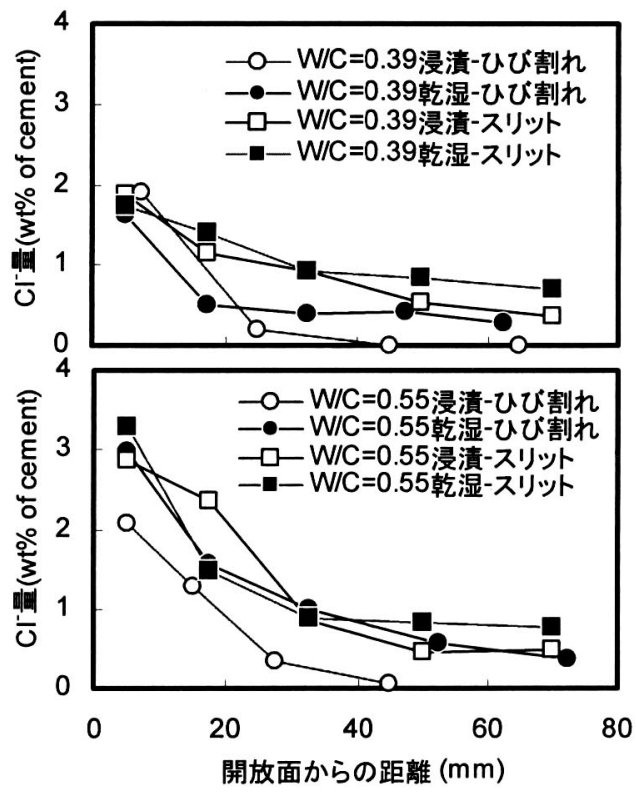

図-3ひび割れ部の $\mathrm{Cl}^{-}$量分布

表- 2 試験前後のひび割れ幅の変化

\begin{tabular}{c|c|c|c|c}
\hline 環境 & \multicolumn{2}{|c|}{ 浸漬 } & \multicolumn{2}{c}{ 乾湿繰返し } \\
\hline W/C & 0.39 & 0.55 & 0.39 & 0.55 \\
\hline 試験前 & 0.090 & 0.070 & 0.10 & 0.088 \\
\hline 試験後 & 0.030 & 0.040 & 0.062 & 0.070 \\
\hline \multicolumn{4}{|c}{} \\
\hline
\end{tabular}

\section{（2）ひび割れを有するコンクリート中の塩化物イオ ン移動性状}

図- 3 にひび割れ部におけるひび割れ深さ方向の $\mathrm{Cl}^{-9}$ 量分布を示す. ひび割れ部の $\mathrm{Cl}^{-}$量は, 開放面が最 も高くひび割れ深さ方向に進むにしたがって小さく なった. 水セメント比 W/C を比較すると, W/C $=0.55$ の方がやや $\mathrm{Cl}^{-}$量が多い傾向を示しており，また，環 境条件について比較すると, 乾湿繰返し環境下の方 


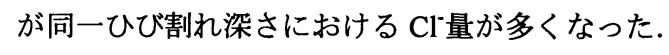

ここで，実験開始前および終了後における各試験 体のひび割れ幅の変化状況を表- 2 に示す.ひび割れ 試験体の開放面におけるひび割れ幅(平均)は試験期 間中に変化しており，また，ひび割れ内部は複雑な 形状となっている ${ }^{4)}$ た, この試験体からひび割れ がコンクリート中の Cl移動に及ぼす影響を同定す ることは困難である.そこで, 深さ方向の幅も $0.20 \mathrm{~mm}$ 一定であるスリット試験体について, 同様に スリット部の $\mathrm{Cl}^{-}$量の測定を行った. 結果を図- 3 に 併せて示す. スリット試験体もひび割れ試験体と同 様, 開放面に $\mathrm{Cl}^{-}$量を多く含み, ひび割れ深さ方向に

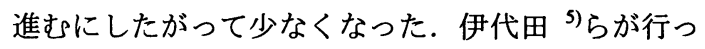
た曲げひび割れを有するコンクリートのひび割れ部 と健全部の塩分浸透梁さの比較実験においても，こ の現象は確認されており，ひび割れ面からの塩分浸 透深さ(ひび割れ垂直方向)は, 開放面からの塩分浸 透深さよりも小さい傾向にあると報告されている.

以上のことから, ひび割れ深さの増加に伴うひび 割れ部 Cl量の减少は, ひび割れ幅およびスリット幅 の変化に拘わらず生じるものであり,ひび割れ中の $\mathrm{Cl}^{-}$量とひび割れ中からひび割れ部へ侵入する $\mathrm{Cl}^{-}$の 移動量の大小関係によって生じるものと考えられる. したがって, 本研究では, ひび割れ中の $\mathrm{Cl}$ 移動を拡 散と仮定し，ひび割れ中ーひび割れ部における $\mathrm{Cl}^{-}$ の移動を, 任意の溶液濃度（ひび割れ中の $\mathrm{Cl}^{-}$濃度） に対する表面塩分量 (ひび割れ部 $\mathrm{Cl}^{-}$量) の関係をも とに考慮することによって，ひび割れを有するコン クリート中の Cl移動を表現することとした:

\section{3. ひび割れを有するコンクリート中の塩化物 イオン移動性状のモデル化}

コンクリート中の Cl移動予測を試みた既往の研 究の多くは, 濃度勾配を駆動力とする Fick 則に従い $\mathrm{Cl}^{-}$移動を定式化している．しかし， $\mathrm{Cl}^{-}$の固定化，吸 着, また, 乾湿繰返し環境下においては移流の発生 等, 実際の移動形態は複雑なメカニズムを伴う。丸 屋 ${ }^{6)}$ は,コンクリート中の $\mathrm{Cl}^{-}$移動を実現象に基づい て詳細に表現した汎用的なモデルを提案し, 種々の 配合・環境下における Cl移動予測を行っている.し かし，これには複数の実験データや逆解析等が必要 であり，Cl移動予測を行うためのプロセスが複雑で ある. そこで, 本研究では容易な実験・解析により Cl'移動予測を合理的に行うことを重視した.

本研究では， Cl移動現象を見かけの拡散現象とし て表現し単純化して取扱う。対象とする塩分は，固

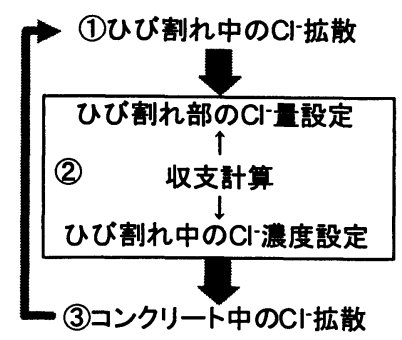

図-4 Cl-移動解析の基本的な流れ（浸漬）

定化や吸着等, 全ての Cl移動に関わる機構が含まれ た結果である全塩分量である。

図- 4 に Cl-移動モデルの概要を示す. 提案モデル は,

(1)ひび割れ中の $\mathrm{Cl}^{-}$拡散

(2)ひび割れ部の $\mathrm{Cl}^{-}$量の設定・ひび割れ中-ひび割れ

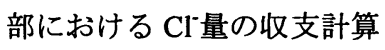

(3)コンクリート中の $\mathrm{Cl}^{\text {拡散 }}$

より構成される.

ここで，ひび割れ部はひび割れ中の $\mathrm{NaCl}$ 溶液と 接しているため, 開放面と同様に取り扱うことが妥 当であると考えられる. 丸屋 ${ }^{6)}$ は, コンクリート表 層部の移動機構を濃度拡散と擬似吸着により説明し ている. 通常, 溶液濃度は $3.0 \% \mathrm{NaCl}$ 一定であるた め, 擬似吸着の流束はコンクリート表層部のみに依 存する形としても問題はない. しかし，前述のよう に,ひび割れ中の溶液濃度は,ひび割れ中の $\mathrm{Cl}^{-}$の拡 散とひび割れ中からひび割れ部への $\mathrm{Cl}^{-}$の移動量に よって深さ毎に異なることが考えられるため, 流束 は溶液濃度と表層部の $\mathrm{Cl}^{-}$濃度の関数として定義し ておく必要がある. しかし, 現状では擬似吸着の流 束を実験的に決定することは困難である.そこで, 本研究では, 開放面における表面塩分量の設定方法 をひび割れ部にも拡張して用いることとした．つま り, ひび割れ部の表面塩分量は, ひび割れ中の $\mathrm{Cl}^{-}$ 濃度により決定される。このとき，ひび割れ中から ひび割れ部への $\mathrm{Cl}^{-}$侵入に関して, 両領域の $\mathrm{Cl}^{-}$量 の大小関係および質量保存を考慮することにより，

濃度拡散と擬似吸着の現象をマクロ的にモデル化す る.ひび割れ部で生じている現象へのアプローチは 実現象と異なるが, 提案するモデルは得られる事実 のみを利用したものであり，ひび割れを有するコン クリート中の $\mathrm{Cl}^{-}$移動の評価方法として簡便なモデ ルである.

次節より，以上の解析条件の設定について詳細を 説明する. 
（1）ひび割れ中の塩化物イオン移動性状

ここではひび割れ中の $\mathrm{Cl}^{-}$濃度分布を解析で得る ために,ひび割れ中の見かけの $\mathrm{Cl}^{-}$拡散係数を実験的 に求めた。これは, 以下に述べる拡散セル試験にて 把握した.

\section{a) 実験概要}

図- 5 に試験体概要を示す。試験体は 2. (1)のコン クリートと同時に作成し, 配合は表- 1 と同様である. 養生後, 割裂引張試験によりひび割れを設けた。割 裂後, 試験体周囲をエポキシ樹脂によりコーティン グし厚さ約 $30 \mathrm{~mm}$ に切断した後, マイクロスコープ を用いてひび割れ幅を測定した。この後表記するひ び割れ幅は, 切断後試験体の両面におけるひび割れ 幅 5 点 $\times 2$ 面の平均值である. 試験体は拡散試験前 に，真空ポンプを用いて飽水状態とした．また，鋼 製のスリット試験体 (スリット長さ $80 \mathrm{~mm}$, 幅 0.025 $\sim 0.20 \mathrm{~mm}$ ）についても同様に拡散試験を行った.こ れは, 割裂試験体の割裂破断面と比較してひび割れ

(スリット) 内部が平滑であり, 試験体両面におけ るひび割れ幅の変化がほとんど無いため,ひび割れ 中の $\mathrm{Cl}$ 拡散の基礎性状把握に最適と考えたためで ある.

図- 6 に Cl-拡散試験の概要を示寸. 試験体はシリ コンゴムを用いて拡散セルにセットし，一方のセル に $\mathrm{NaCl} 3.0 \%$ 溶液, 他方には蒸留水を満たした. この とき,コンクリート打設面側を $\mathrm{NaCl}$ セルに, 型枠 面側を $\mathrm{H}_{2} \mathrm{O}$ (蒸留水)セルに同時にセットした. $40^{\circ} \mathrm{C}$ 一定環境下で拡散試験を開始し, $\mathrm{NaCl}$ および $\mathrm{H}_{2} \mathrm{O}$ セルにおける Cl濃度変化を塩分分析計にて測定し た. また, スリット試験体については, 比較のため に $20^{\circ} \mathrm{C}$ 環境下についても試験を行った.

b) 塩化物イオンの移動評価方法

$\mathrm{Cl}^{\prime}$ 拡散係数 $D$ は式 $(1)^{7)}$ から求める.

$$
J=\frac{V_{\mathrm{H}_{2} \mathrm{O}}}{A} \frac{d C_{\mathrm{H}_{2} \mathrm{O}}}{d t}=\frac{D}{l}\left(C_{\mathrm{NaCl}}-C_{\mathrm{H}_{2} \mathrm{O}}\right)
$$

ここに, $J: \mathrm{H}_{2} \mathrm{O}$ セルへのイオン流速, $A:$ 試験体断 面積, $l$ : 試験体厚さ, $V_{\mathrm{H} 2 \mathrm{O}}: \mathrm{H}_{2} \mathrm{O}$ セル内の溶液体積, $C_{\mathrm{NaCl}}, C_{\mathrm{H} 2 \mathrm{O}}$ : 試験体表面部のイオン濃度

ここではひび割れ内の $\mathrm{Cl}^{-} の$ 拡散を対象とするた め, 試験体断面積としてひび割れ断面積を用いるこ ととした。このとき，スリット試験体は内部が平滑 であるため,ひび割れ断面積（スリット幅×長さ） および移動距離（試験体厚さ）は容易に把握するこ とができる，しかし，割裂試験体の破断面の状況は 表面から把握することは出来ず，それらは実際には

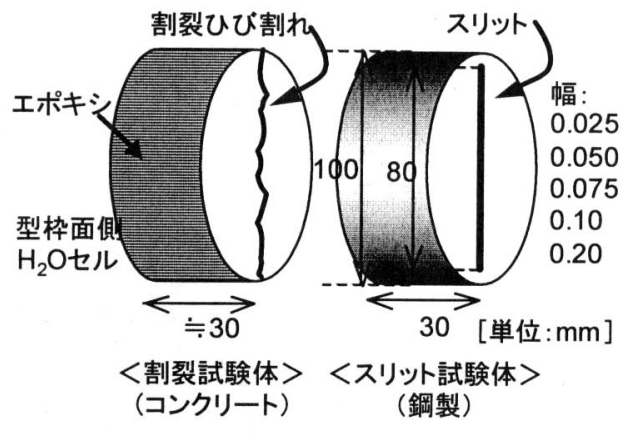

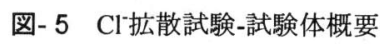

割裂試験体 or スリット試験体

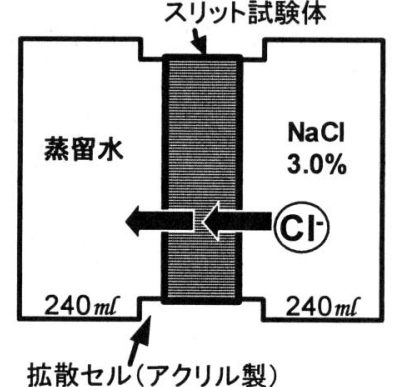

図- $6 \mathrm{Cl}^{-}$拡散試験概要

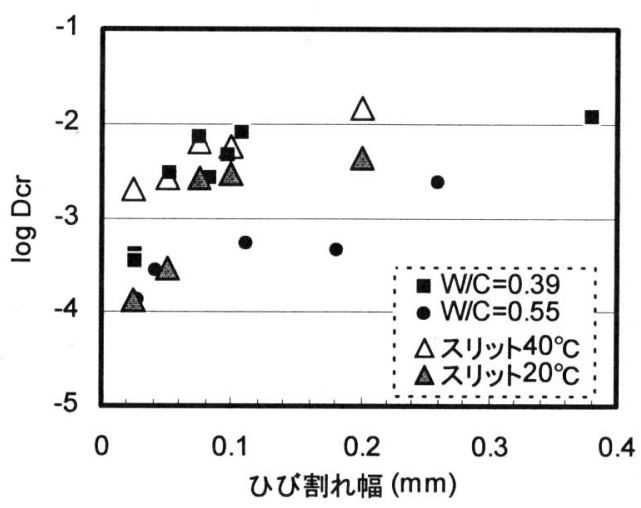

図- 7 ひび割れ幅と $\mathrm{Cl}^{-}$拡散係数の関係

ひび割れ長さや試験体厚さに代表されない，そこで， レーザ変位センサによって割裂破断面を $0.20 \mathrm{~mm}$ 間 隔で測定し，ひび割れ長さおよび試験体厚さを求め た。これを式(1)中で考虑することにより，ひび割れ 中の $\mathrm{Cl}$ 拡散係数を求めた.

c) ひび割れ中の塩化物イオン移動性状

ひび割れ幅とひび割れ中の $\mathrm{Cl}$ 拡散係数 $D_{c r}$ の関係 を図ー7に示す．これより，ひび割れ幅が大きくなる につれて， $\mathrm{Cl}^{l}$ 拡散倸数は大きくなり，ある程度のひ 
び割れ幅（スリット試験体の結果より，ひび割れ幅 $0.075 \mathrm{~mm}$ ） 以上では拡散係数は収束することが考 えられる.W/C に注目した場合, W/C $=0.39$ では $40^{\circ} \mathrm{C}$ スリット試験体と同程度のひび割れ幅と $\mathrm{Cl}^{-}$拡散係 数の関係となっている. しかし, W/C $=0.55$ のひび割 れ幅と $\mathrm{Cl}$ 拡散係数の関係は, $\mathrm{W} / \mathrm{C}=0.39$ と比較して 1 オーダー程度小さな值となった．W/C の大きいゴ ンクリートは空隙が多いため, W/C の小さなものと 比較するとコンクリート自体の拡散係数が大きくな る. したがって, W/C $=0.55$ の場合, 破断面からコン クリート内部に $\mathrm{Cl}^{-か ゙}$ 侵入したことが考えられる.一 般に, $\mathrm{Cl}$ のセメント硬化体内の移動現象においては, Clの固定化現象が拡散現象と共に発生しており, 単 純な物質移動現象として捉えることは困難と考えら れている．拡散セル試験から得られたひび割れの無

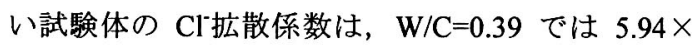
$10^{-9} \mathrm{~cm}^{2} / \mathrm{sec}, \mathrm{W} / \mathrm{C}=0.55$ では $1.41 \times 10^{-8} \mathrm{~cm}^{2} / \mathrm{sec}$ であり, ひび割れ中の $\mathrm{Cl}^{-}$拡散係数と比較して $10^{-5}$ 倍程度の值 となった.これらは，拡散・固定化等を経たのちに $\mathrm{H}_{2} \mathrm{O}$ セルに到達した $\mathrm{Cl}^{\circ} よ り$ 得られた, 移動可能な $\mathrm{Cl}^{-}$の拡散係数である.ひび割れ中の $\mathrm{Cl}^{-}$の拡散におい てもそれらが生じていると考えられるが, 割裂試験 体の結果と固定化を生じにくいと考えられる鋼製ス リット試験体の拡散係数がほぼ同じであったことか ら，その影響は無視できる程度であったと考えられ る. したがって，提案モデル中ではスリット試験体 から得られた見かけの Cl昖散係数を用いた。 なお, 今回得られたひび割れ中の $\mathrm{Cl}^{-}$拡散係数は, 全て, 希 薄電解溶液中の $\mathrm{Cl}^{-}$拡散係数よりも大きい值であっ た.これについては現段階では不明であり，今後の 検討課題とする.

\section{(2) ひび割れ中-ひび割れ部間の塩化物イオン量の 収支計算}

ここでは, コンクリートひび割れ部の $\mathrm{Cl}^{-}$量を設定 する. 任意の溶液濃度に対する $\mathrm{Cl}^{-}$量の定式化を行う にあたり，ひび割れの無いコンクリートの開放面か ら $5 \mathrm{~mm}$ までの $\mathrm{Cl}^{-}$量の経時変化を実験的に把握した. コンクリートの配合および諸性質は表- 1 と同様で あり，試験体寸法は $\phi 100 \times 100 \mathrm{~mm}$ である， 円柱底 面を開放面とした $1.0,2.0,3.0,5.0 \% \mathrm{NaCl}$ 水溶液への 浸漬を 4,7,13,17 週間行い, 前述した方法により全塩 分量を測定した. 浸漬期間中, $\mathrm{NaCl}$ 濃度は常時一定 であり，水溶液の温度は $40^{\circ} \mathrm{C}$ 一定である.

図- 8 に W $/ \mathrm{C}=0.39$ および 0.55 の $\mathrm{NaCl}$ 水溶液濃度 毎の $\mathrm{Cl}^{-}$量の経時変化を示す. $\mathrm{Cl}^{-}$量は水溶液濃度が高 いほど多く，ある時期よりそれぞれの水溶液濃度お よびW/C において一定値に収束する. 既往の研究よ

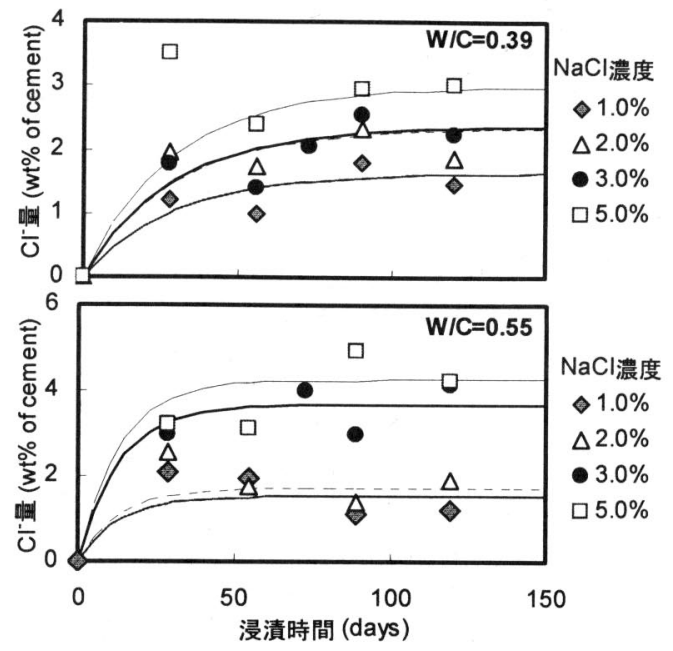

図- 8 表面塩分量の経時変化

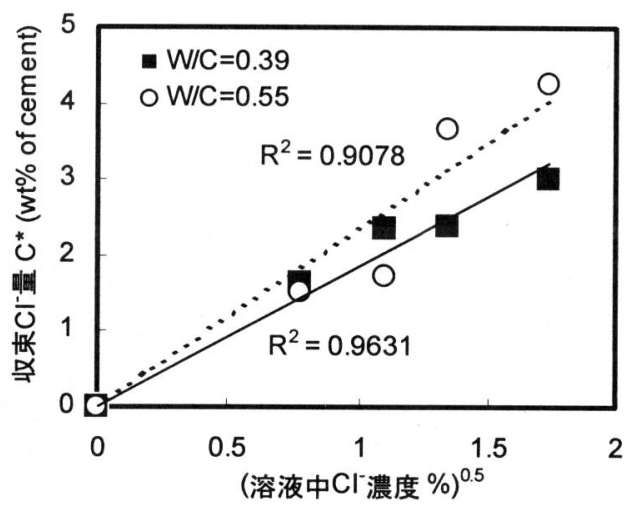

図-9 収束塩分量 $C^{*}$ と溶液濃度の関係

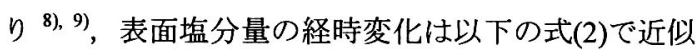
できる.

$$
C_{0}(t)=C^{*}\{1-\exp (-b t)\}
$$

ここに, $C_{0}(t)$ : 表面塩分量, $t$ : 試験期間, $C^{*}, b$ : 倸数

ここで, $C^{*}$ は収束塩分量を表し， $b$ は収束速度を 表す係数である. 竹田ら ${ }^{99}$ はセメントペースト

（W/C $=0.35 \sim 0.80 ）$ の浸漬試験加可溶性塩分の経 時変化について検討しており, 収束速度は W/C が大 きくなるにつれて速くなると報告している.これよ $\eta, b$ は試験体の内部構造により変化する係数と考 えられ，配合が等しければ溶液濃度によらず $b$ は一 定と考えることができる．これに基づいて，式(2)に より回帰分析を行った結果を図-8に合わせて示す. 


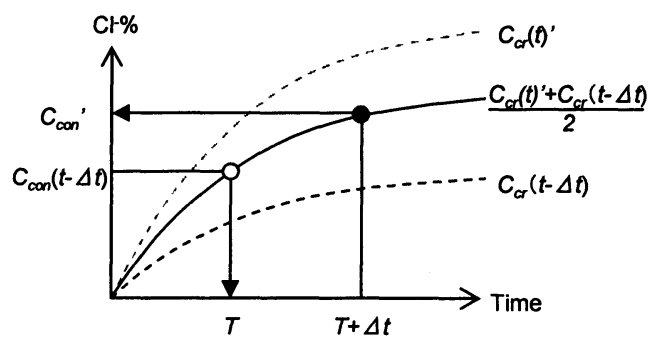

図-10ひび割れ部 $\mathrm{Cl}^{-}$量の設定

以上の様に決定された溶液濃度毎の収束塩分量 $C^{*}$ と溶液濃度（雲囲気濃度）の関係を図- 9 に示す. 収束塩分量 $C^{*}$ と雾囲気濃度の $1 / 2$ 乗には相関関係が 認められ，W/C 毎にほぼ直線で近似できる結果とな った.これより, 各雰囲気濃度における収束塩分量 は，以下の式(3)のように表すことができる.

$$
C^{*}=\left(C_{c r}\right)^{1 / 2} \cdot a
$$

ここに, $C^{*}$ : 収束塩分量, $a$ : 図-9 中の近似直線の

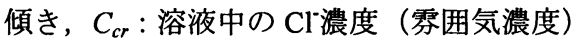

図- 10 に解析におけるひび割れ部 $\mathrm{Cl}^{\text {量の設定方 }}$ 法の概念を示す。ここで，任意の時間 $t$ におけるひ び割れ中の任意の位置における $\mathrm{Cl}^{-}$濃度を $C_{c r}(t)$ 'とし

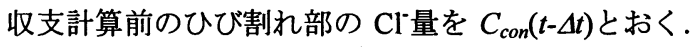
$C_{c o n}(t-\Delta t)$ は前ステップにおいて収支計算を経て求め られた濃度である.ここで, $t-\Delta t$ から $t$ におけるひび 割れ中の雾囲気濃度を $\left(C_{c r}(t){ }^{\prime}+C_{c r}(t-\Delta t)\right) / 2$ と近似的 に表すと， $C_{c o n}(t-\Delta t)$ はこれを雰囲気濃度とする表面 塩分量として, 仮想時間 $T$ を用いて式(2)と同様に表 すことができる.

$$
C_{c o n}(t-\Delta t)=C_{\left(C_{c r}(t)+C_{c r}(t-\Delta t)\right) / 2}\{1-\exp (-b(T))\}
$$

ここに， $C_{\left.(\cos (t))^{+}+\cos (t-\Delta t)\right) / 2}$ : 雾曲気濃度 $\left(C_{c r}(t)^{\prime}+\right.$ $\left.C_{c r}(t-\Delta t)\right) / 2$ のときの収束塩分量

仮想時間 $T$ から $\Delta t$ 経過時の $\mathrm{Cl}^{-}$量を時間 $t$ における ひび割れ部 $\mathrm{Cl}^{-}$量とすると,式(4)より求めることがで

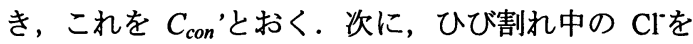
コンクリートひび割れ部へ供給するための収支計算 を行う。このとき，受け渡しに使用する領域面積を ひび割れ中において $A_{c r}$ ，コンクリートにおいて $A_{c o n}$ とすると, 両領域中の $\mathrm{Cl}^{-}$総量のつり合いより, 両領 域の $\mathrm{Cl}^{-}$量が決定される.
以上の収支計算の結果として得られる $C_{c o n}(t)$ は, コンクリート全体の拡散解析において使用され, $C_{c r}(t)$ は次ステップのひび割れ中の $\mathrm{Cl}^{-}$拡散解析にお いて初期濃度となる。

（3）開放面における表面塩分量およびコンクリート の塩化物イオン拡散係数

前節(2)で述べた $3.0 \% \mathrm{NaCl}$ 水溶液浸漬実験の表面 塩分量の経時変化より, 開放面の境界条件は式(5)お よび(6)の様に表せる.

$$
\begin{aligned}
& \mathrm{W} / \mathrm{C}=0.39: C_{0}(t)=2.40 \cdot\{1-\exp (0.034 t)\} \\
& \mathrm{W} / \mathrm{C}=0.55: C_{0}(t)=3.67 \cdot\{1-\exp (0.076 t)\}
\end{aligned}
$$

コンクリートの見かけの拡散係数は，(2)と同じ試 験体より得られた $\mathrm{Cl}^{-}$量分布 $(\mathrm{NaCl} 3.0 \%-13$ 週間浸 漬）から求めた。境界条件を式(2)とした場合の Fick 則の厳密解 ${ }^{10)}$ より, コンクリートの見かけの拡散係 数は, W/C $=0.39$ のとき $D_{c o n}=1.39 \times 10^{-7} \mathrm{~cm}^{2} / \mathrm{sec}, \mathrm{W} / \mathrm{C}$ $=0.55$ のとき $D_{c o n}=2.13 \times 10^{-7} \mathrm{~cm}^{2} / \mathrm{sec}$ と算出された.

ここで, 既往の研究において, コンクリートの $\mathrm{Cl}^{-}$ 拡散係数は時間依存する傾向があると指摘されてい $3^{11)}$. ᄂかし, 本研究では $\mathrm{Cl}$ 拡散係数の時間依存性 については考慮せず, 浸漬 13 週試験体から得られた 見かけの拡散係数を用いることとした.

以上の境界条件, $\mathrm{Cl}^{-}$拡散係数, および(2)で算出さ れたひび割れ部 $\mathrm{Cl}^{-}$量を初期值として，ひび割れを有 するコンクリートの Cl移動性状を再現した. 解析モ デルにおいては，開放面からひび割れ奥行き方向ま でひび割れ幅は一定として設定した.

\section{(4) 解析モデルの検証}

構筑したモデルの妥当性について, スリット幅が $0.20 \mathrm{~mm}$ 一定であるスリット試験体により検証を行 った．図- 11 に，W/C $=0.39$ および 0.55 における解 放面からの距離とひび割れ部 $\mathrm{Cl}^{-}$量の関係を示す.プ ロットは実測值を示し，実線は解析值を示す．図よ り, 解析値は実験值を概ね再現していることが分か る.

次に, 図-12に EPMA 分析から得られたスリット 試験体の $\mathrm{Cl}^{-}$量分布と, 解析より得られた $0.20 \mathrm{~mm}$ の

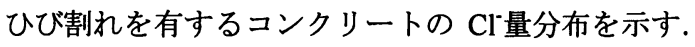
こちらも,解析結果は実験結果を概ね評価しており， $\mathrm{W} / \mathrm{C}=0.39$ の場合はコンクリート自体の拡散係数が 小さいため, $\mathrm{W} / \mathrm{C}=0.55$ の結果と比較して, ひび割れ からひび割れ部，そしてコンクリート内部への $\mathrm{Cl}^{-}$ 


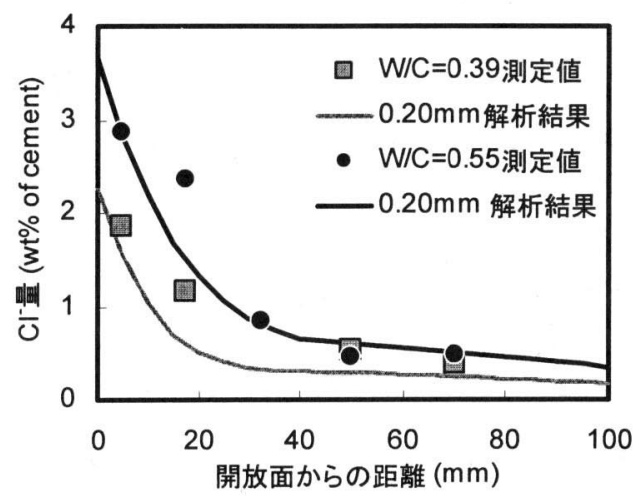

図-11ひび割れ部 $\mathrm{Cl}^{-}$量分布（浸漬 13 週）

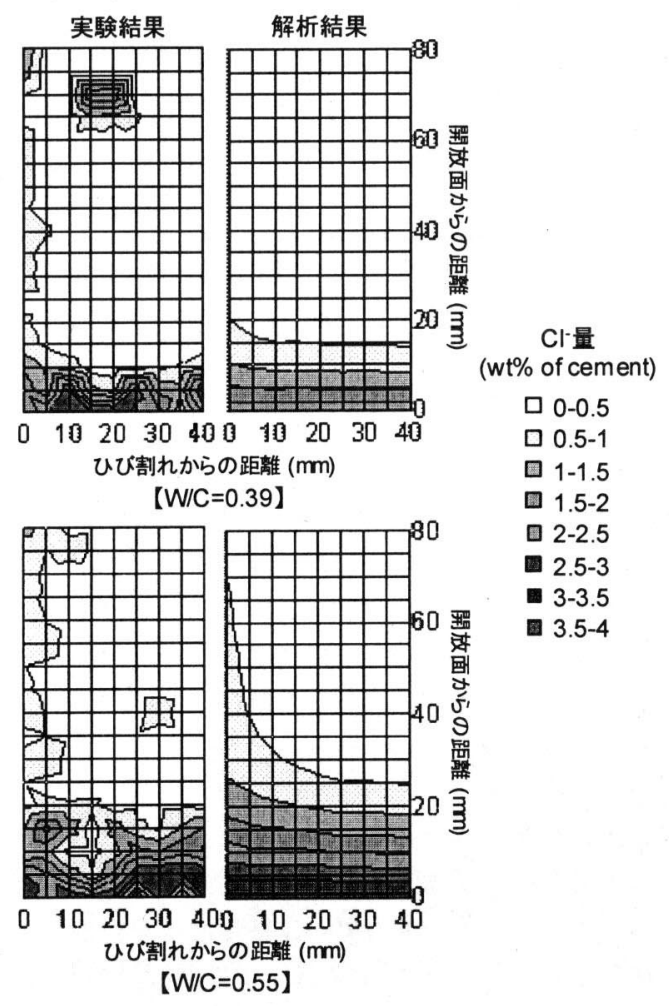

図-12 $\mathrm{Cl}^{-}$量分布（浸漬 13 週）

の移動が抑制されていることが分かる.ひび割れ試 験体のひび割れ部およびその周辺についても同様に， 解析值は実験值を概ね評価することが可能であった.

以上より, 開放面における表面塩分量の設定方法 をひび割れ部にも拡張し、ひび割れ中ーひび割れ部 の $\mathrm{Cl}^{-}$量に対する質量保存則を考慮した本解析は，実 現象におけるひび割れを有するコンクリート中の $\mathrm{Cl}^{-}$の移動評価が可能であると考えられる.

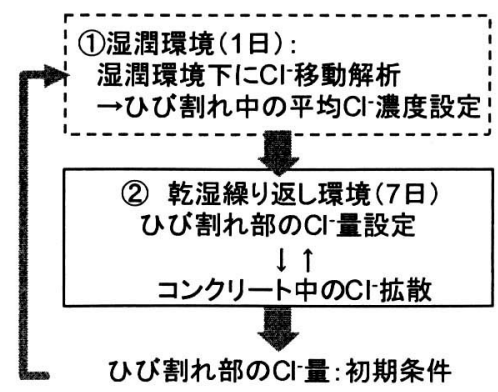

図-14 $\mathrm{Cl}^{-}$移動解析の基本的な流れ（乾湿繰返し）

\section{4. 乾湿繰返し環境下におけるコンクリート中 の塩化物イオン移動性状のモデル化}

ここでは，コンクリート中で生じる現象として考 えられる濃度拡散や吸着および固定化以外に, 吸 水・乾燥に伴って移流が発生すると考えられる,乾湿 繰返し環境下におけるコンクリート中の $\mathrm{Cl}$ 移動評 価モデルの構築を行う. 本研究では, 乾湿繰返し環 境下における Cl移動性状を, 環境条件におけるマク ロ的アプローチとして, 乾燥および湿潤の環境を問 わず，常に平均的に移動すると仮定して表現する.

乾湿繰返し環境下における Cl移動解析の概要を 図-14 に示す. 解析は,

(1)湿潤環境下における Cl-移動解析

(2)ひび割れ部の $\mathrm{Cl}^{-}$量の設定とコンクリート中の $\mathrm{Cl}^{-}$ 拡散 (乾湿繰返し環境)

より構成される. コンクリートの乾湿繰返しサイク ルが，湿潤 1 日 +乾燥 6 日 $=7$ 日間の場合，まず， 1 日間の湿潤環境下における移動計算を行う。これは, 3 章で示したモデルである.これより, 湿潤期間中 のひび割れ中の平均 $\mathrm{Cl}$ 濃度 (雾囲気濃度) を求める.

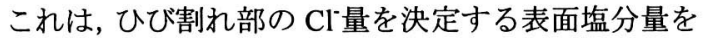
湿潤時の溶液濃度に依存する形で定式化しているた めである. 次に, 湿潤解析から得られた情報をもと に，乾湿繰返し環境(7日間)の移動解析を行う。この とき, 開放面における境界条件およびコンクリート 中の拡散係数は, 乾湿繰返し試験結果を式(2)および 式(3)に適用して求める. また, ひび割れ部では, 湿 潤環境のひび割れ中雰囲気濃度と乾湿繰返し環境下 における境界条件式, および式(3)を用いて $\mathrm{Cl}^{\text {量が設 }}$ 定される.

以上の $\mathrm{Cl}^{-}$移動解析条件の詳細について,(1)開放面 における境界条件とコンクリートの $\mathrm{Cl}^{-}$拡散係数, (2) ひび割れ部の $\mathrm{Cl}^{-}$濃度の設定, の順に詳細に説明する. 
(1) 開放面における境界条件とコンクリートの塩化 物イオン拡散係数の設定

境界条件となる開放面における表面塩分量のモデ ル化を行うにあたり，ひび割れの無いコンクリート

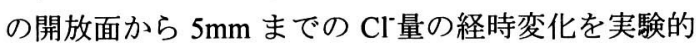
に把握した。コンクリートの配合および諸性質は表 - 1 と同様であり, 試験体寸法は $\phi 100 \times 100 \mathrm{~mm}$ であ る. 円柱底面を開放面とした開放面 1 面のみを浸 漬・乾燥面として，1 日間の $3.0 \% \mathrm{NaCl}$ 水溶液浸漬お よび 6 日間の乾燥（相対湿度 $60 \%$ ）を 1 サイクルと する乾湿繰返し試験を行った。浸漬期間中, $\mathrm{NaCl}$ 濃度は常時一定であり，また環境温度は乾燥・浸漬 ともに $40^{\circ} \mathrm{C}$ 一定である.

ここで, 乾湿繰返し環境下における表面塩分量は, 乾燥・湿潤に伴い複雑に変化することが考えられる が，本研究では乾燥期間中日に試料の採取を行うこ とにより表面塩分量の変化を平均的に表現できると 仮定し，これに対応するコンクリート中の Cl-拡散係 数を用いて移動性状を表現した．表面塩分量は，実 験結果を湿潤環境下と同様に式(2)に適用し, W/C 毎 に設定した．表面塩分量の経時変化は，式(7)および (8)の様に表せる.

$$
\begin{aligned}
& \mathrm{W} / \mathrm{C}=0.39: C_{0}(t)=1.67 \cdot\{1-\exp (0.13 t)\} \\
& \mathrm{W} / \mathrm{C}=0.55: C_{0}(t)=2.75 \cdot\{1-\exp (0.15 t)\}
\end{aligned}
$$

ひび割れの無い試験体より得られた $\mathrm{Cl}^{-}$濃度分布 （乾湿繰返し 13 サイクル経過）から，見かけの $\mathrm{Cl}^{-}$ 拡散倸数は, $\mathrm{W} / \mathrm{C}=0.39$ のとき $D_{c o n}=8.10 \times 10^{-8}$ $\mathrm{cm}^{2} / \mathrm{sec}, \mathrm{W} / \mathrm{C}=0.55$ のとき $D_{c o n}=1.96 \times 10^{-7} \mathrm{~cm}^{2} / \mathrm{sec}$ と 算出された.

\section{(2) ひび割れ部の塩化物イオン濃度の設定}

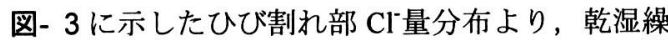
返し環境下においても湿潤環境と同様，ひび割れ中 の $\mathrm{Cl}^{-}$量とひび割れ部へ侵入する $\mathrm{Cl}^{-}$の移動量の大小 関係を考慮する必要があると考えられる.このため, 各サイクルにおけるひび割れ中の平均 $\mathrm{Cl}^{-}$濃度を算 出する必要がある．本解析では， 3 章に述べた湿潤 環境下の $\mathrm{Cl}$ 移動解析を, 実際の湿潤期間行うことに より,ひび割れ中の平均的な $\mathrm{Cl}^{-}$濃度（䨌囲気濃度） を求める．これを基に，各サイクルにおける乾湿繰 返し環境下のひび割れ部 $\mathrm{Cl}^{-}$量を決定する.

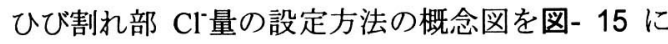
示す. まず，任意の時間 $t$ におけるひび割れ部 $\mathrm{Cl}^{-}$量 を $C_{c o n}(t)$ とし, 開放面からの高さ $x$ におけるひび割

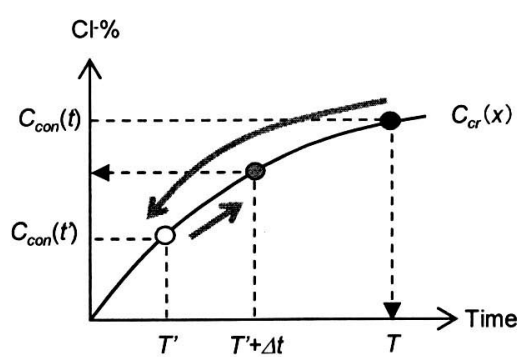

図-15 ひび割れ部 $\mathrm{Cl}^{-}$量の設定

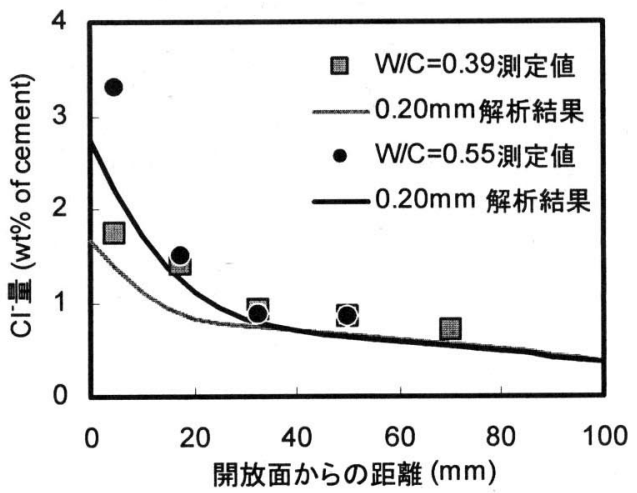

図-16ひび割れ部 $\mathrm{Cl}^{-}$量分布（乾湿 13 週）

れ中の $\mathrm{Cl}^{-}$濃度を $C_{c r}(x)$ とする．雾囲気濃度とひび割 れ部の収束塩分量の関係が式(3)で表せるとすると，

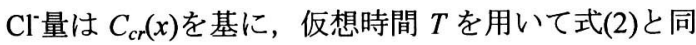
型式で表すことができる．ここで，Cl゙はコンクリー 卜全体に拡散するため,ひび割れ部 $\mathrm{Cl}^{-}$量は堿少し $C_{c o n}\left(t^{\prime}\right)\left(\mathrm{Time}=T^{\prime}\right)$ となる. $t+\Delta t$ 時の $\mathrm{Cl}^{-}$量は, 拡散後 の $\mathrm{Cl}^{-}$量 $C_{c o n}\left(t^{\prime}\right)\left(\mathrm{Time}=T^{\prime}+\Delta t\right)$ を基に, 式(2)より $C_{c o n}(t+\Delta t)$ と表せる.

以上の境界条件， $\mathrm{Cl}$ 拡散係数，およびひび割れ部

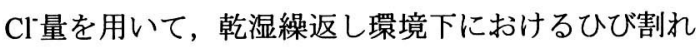
を有するコンクリート中の Cl移動性状を再現した. 本解析を行うには，コンクリートの湿潤環境および 乾湿繰返し環境下における $\mathrm{Cl}^{-}$移動性状の双方を実 験的に把握することが必要である. また, 現時点で は，湿潤・乾燥状態をサイクルとして表せる環境下 の $\mathrm{Cl}^{-}$移動性状のみ表現できるモデルであることを 特記する.

\section{(3) 解析モデルの検証}

構築したモデルの妥当性について，スリット幅が $0.20 \mathrm{~mm}$ 一定であるスリット試験体により検証を行 った. 図- 16 に, W/C $=0.39$ および 0.55 における解 放面からの距離とひび割れ部 $\mathrm{Cl}^{-}$量の関係を示す.プ 
ロットは実測値を示し，実線は解析値を示す．これ より, 乾湿繰り返し環境における解析結果は実験值 を概ね評価していることが分かる．ひび割れ試験体 のひび割れ部についても同様に，解析值は実験值を 概ね評価することが可能であった。しかし，スリッ ト梁さ（ひび割れ深さ）に対する $\mathrm{Cl}^{-}$量の減少は実験 值と同様の傾向を示しているが，いずれの位置にお いても実験値より低い $\mathrm{Cl}^{-}$量となった. これについて は, 式(7)および(8)における表面塩分量の設定が原因 と考えられる.

濱田・Swamy ${ }^{11)}$ によれば，海中では比較的早期に コンクリート表面の塩分含有量がほぼ一定となるの に対し, 干満部ではデータが得られている範囲で 10 年, 飛沫部では 20 年まで増加する. 本研究では, 収 束塩分量 $C^{*}$ と係数 $b$ (表面塩分量が一定となる時間 を決定する係数）を，短期間の試験結果より設定し た.これが適切でなければ，式(3)として表した雲囲 気浱度と収束塩分量の関倸も不適切なものとなり, 結果として，ひび割れ中-ひび割れ部の $\mathrm{Cl}^{-}$移動量の 適切な表現が不可能となる。 したがって，Cl移動性 状の予測精度を向上させるためには，特に表面塩分 量の経時変化式の設定が重要であるといえる.

\section{5. 提案モデルを用いた塩化物イオン移動評価 の一般化の可能性について}

提案モデルは, 対象とするコンクリートに関して, (1)ひび割れ幅, (2)環境 $\mathrm{Cl}$ 濃度, (3)表面塩分量の経時 変化, (4)コンクリート中の $\mathrm{Cl}^{-}$拡散係数, (5)ひび割れ 中の $\mathrm{Cl}$ 拡散係数, (6)乾湿サイクル条件，が把握され れば，湿潤・乾湿繰返し環境下におけるコンクリー ト中の $\mathrm{Cl}^{-}$移動性状の推定が可能となる.

ここで，(1)ついては目視による把握の他に，非 破壊試験を用いて詳細な情報を得ることができる. さらに, ひび割れ幅が $\mathrm{Cl}$ の移動に及ぼす影響が解明 されれば, 詳細点検の有効範囲を示すことが可能と なる. また, (5)ひび割れ中の $\mathrm{Cl}^{-}$拡散係数は 3 章(1) に示した実験より求めることができる. しかし, 対 象とするひび割れ幅・環境温度毎に，ひび割れ中の 拡散係数を求めることは効率的ではない。 また，ひ び割れ中の拡散係数はコンクリート自体の見かけの 拡散係数よりも $10^{5}$ 倍程度大きく, これがコンクリ 一ト中の移動性状にどれほど影響を与えるのか不明 である.そこで，ひび割れ幅およびひび割れ中の拡 散係数がひび割れを有するコンクリート中の $\mathrm{Cl}$ 移 動評価に及ぼす影響について，解析的に検討を行っ た.

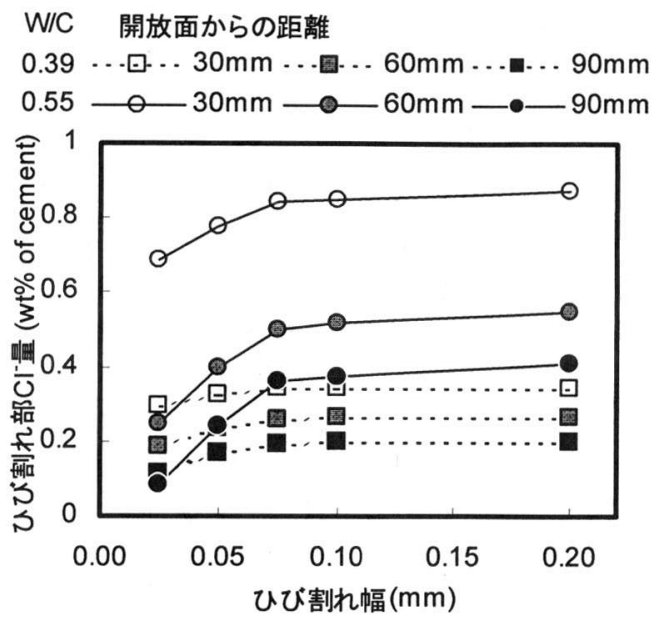

図-17 ひび割れ幅とひび割れ部 $\mathrm{Cl}^{-}$量の関係

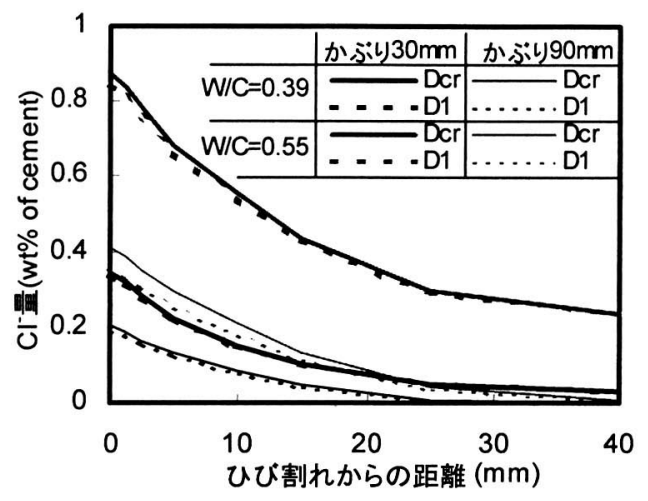

図-18ひび割れ中の $\mathrm{Cl}^{-}$量拡散係数の影響

\section{（1）ひび割れ幅が塩化物イオン侵入に及ぼす影響}

図-17に，ひび割れ幅とひび割れ深さ $30,60,90 \mathrm{~mm}$ におけるひび割れ部 $\mathrm{Cl}^{-9}$ 量の関係（浸漬 13 週-解析結 果）を示す．なお，ひび割れ中の $\mathrm{Cl}$ 拡散係数は，第 3 章(1)鋼製スリット試験体より求められた值を用い た。いずれのひび割れ染さにおいても， $\mathrm{Cl}^{-}$量はひび 割れ幅 $0.075 \mathrm{~mm}$ までは増加し, その後 $1.0 \mathrm{~mm}$ まで ほぼ一定となった. また, この現象は $\mathrm{W} / \mathrm{C}=0.39$ と 比較して $\mathrm{W} / \mathrm{C}=0.55$ の方が顕著に表れている. これ より，Cl-供給量を決定するひび割れ幅と， $\mathrm{Cl}^{-}$消費量 を決定するコンクリート自体の $\mathrm{Cl}^{\prime}$ 拡散係数により, コンクリートひび割れ部の $\mathrm{Cl}^{-}$量 (コンクリート全体 への影響も含まれている）は決定され，【供給量＜消 費量】の条件下において，ひび割れ幅がコンクリー トひび割れ部 $\mathrm{Cl}^{-}$量の支配要因となることが考えら れる. また, $\mathrm{W} / \mathrm{C}=0.55$ は $\mathrm{W} / \mathrm{C}=0.39$ と比較してコン クリートの拡散係数が大きく, 結果として $\mathrm{Cl}^{-}$消費量 
表- 3 コンクリートの配合および諸性質

\begin{tabular}{|c|c|c|c|c|c|c|c|c|c|c|}
\hline \multirow{2}{*}{$G \max$} & \multirow{2}{*}{$W / C$} & \multirow{2}{*}{ s/a } & \multicolumn{5}{|c|}{ 単位量 $\left(\mathrm{kg} / \mathrm{m}^{3}\right)$} & \multirow{2}{*}{$\begin{array}{c}\text { 空気至 } \\
\%\end{array}$} & \multirow{2}{*}{$\begin{array}{c}\text { スランフ } \\
\mathrm{cm}\end{array}$} & \multirow{2}{*}{$\begin{array}{c}f_{28} \\
N / m^{2}\end{array}$} \\
\hline & & & $w$ & $\mathrm{C}$ & $S$ & $\mathbf{G}$ & $\mathrm{SP}$ & & & \\
\hline 20 & 0.6 & 0.490 & 161 & 268 & 897 & 974 & 0.80 & 4.0 & 6.1 & 31.7 \\
\hline
\end{tabular}

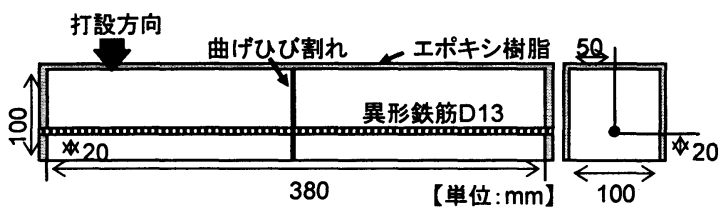

図-19 試験体概要

が多くなる，したがって，ひび割れ幅の減少に伴っ てひび割れ中の $\mathrm{Cl}^{-}$量が不足する現象が顕著に表れ ことが考えられる.

(2) ひび割れ中の塩化物イオン拡散係数が塩化物イ オン侵入に及ぼす影鄂

ひび割れ中の拡散係数が $\mathrm{Cl}^{-}$移動性状に及ぼす影 響を検討するため, ひび割れ幅が一定であり，ひび

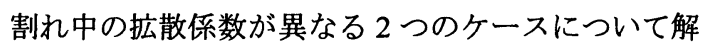
析を行った.

図- 18 に W/C=0.39 および 0.55 のコンクリートに おけるひび割れ中の拡散係数が, コンクリートの $\mathrm{Cl}^{-}$ 量分布に及ぼす影響を示す. 解析モデルのひび割れ 幅は $0.20 \mathrm{~mm}$ であり,ひび割れ中の $\mathrm{Cl}$ 拡散係数とし て, 第 3 章(1)に示した鋼製スリット試験体（スリッ 卜幅 $0.20 \mathrm{~mm}$ ）の実験結果である $1.45 \times 10^{-2} \mathrm{~cm}^{2} / \mathrm{sec}$ $\left(=D_{c r}\right)$, およびスリット幅 $0.025 \mathrm{~mm}$ の実験結果であ る $2.02 \times 10^{-3} \mathrm{~cm}^{2} / \mathrm{sec}(=D 1)$ を使用した.

コンクリートの拡散係数は, 第 2 章(3)で示した浸 漬時の見かけの拡散係数を使用した.解析結果より， ひび割れ部に近いほど, $D_{c r}$ と $D 1$ による $\mathrm{Cl}^{-}$量には 差があり, かぶりが大きいほどその差は大きくなる ことが分かる. また，W/C が大きいほど計算結果に

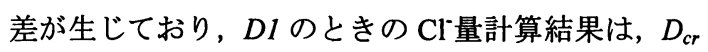
による計算結果よりも，W/C $=0.39$ の時は $5 \%$ 程度, $\mathrm{W} / \mathrm{C}=0.55$ の時は $10 \%$ 程度小さい值となった.

これより，ひび割れ中の $\mathrm{Cl}$ 拡散係数については, その影響程度を認識し有意性を考慮した上で設定す ることが必要である。しかし，安全側の予測をする のであれば，鋼製スリット試験体の結果である 1.45 $\times 10^{-2} \mathrm{~cm}^{2} / \mathrm{sec}$ 程度を用いても実務上問題はないと考 えられる.

（3）提案モデルを用いた塩化物イオン移動評価の一 般化の可能性について

これまでの検討より，提案モデルを使用するには，
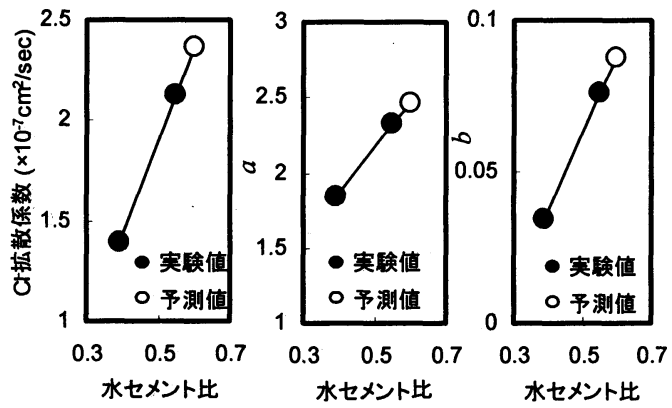

図-20各係数の予測

各環境下における表面塩分量および $\mathrm{Cl}$ 拡散係数を 把握すればよい。ここで, 乾湿繰返し環境下に適用 するには，乾湿繰返し環境下における表面塩分量お よび拡散係数だけでなく，同じ配合条件のコンクリ 一トの湿潤環境下における表面塩分量および拡散係 数を把握することが必要となる. しかし, 湿潤環境 下のそれら係数の把握は,実験室レベルでのみ可能 なことである。つまり, 湿潤環境下における表面塩 分量および拡散係数の環境・材料条件に基づいた一 般化がなされれば, 本研究で構築したモデルはさら に汎用性をもつことが期待される.そこで, 一般化 への試みとして，これまでと異なる配合・環境条件 の試験体を用いて, 提案モデルの適用性について検 討を行った.

\section{a) 実験概要}

セメントは普通ポルトランドセメント, 細骨材は 富士川産川砂, 粗骨材は両神産砕石を用いた。表3 にコンクリートの配合および諸性質を示す.なお， セメント中に含まれる Clは, セメント重量に対し $0.007 \%$ (平均) である.

試験体概要を図- 19 に示す. $100 \times 100 \times 380 \mathrm{~mm}$ の 型枠にコンクリートを打設, 24 時間後脱型し, 材齢 28 日まで $20^{\circ} \mathrm{C}$ 水中養生を行った. 鉄筋はかぶり $20 \mathrm{~mm}$ となるよう試験体の中心に配置した. 養生後, 2 点支持 1 点載荷により試験体下面に曲げひび割れ を設けた. 除荷後, 開口面におけるひび割れ幅を測 定した. その後, ひび割れ開口面を除く 5 面をエポ キシ系樹脂により被覆し, $\mathrm{Cl}$ は 1 面のみから侵入す るとした. $\mathrm{Cl}^{-}$浸透促進試験は, 4 日間の $3.0 \% \mathrm{NaCl}$ 水溶液浸漬, および 3 日間の乾燥（相対湿度 $60 \%$ ） を 1 サイクルとする乾湿繰返し環境とし， $20^{\circ} \mathrm{C}$ 一定 環境下にて 13 サイクルまで行った. 試験終了後, ひ 


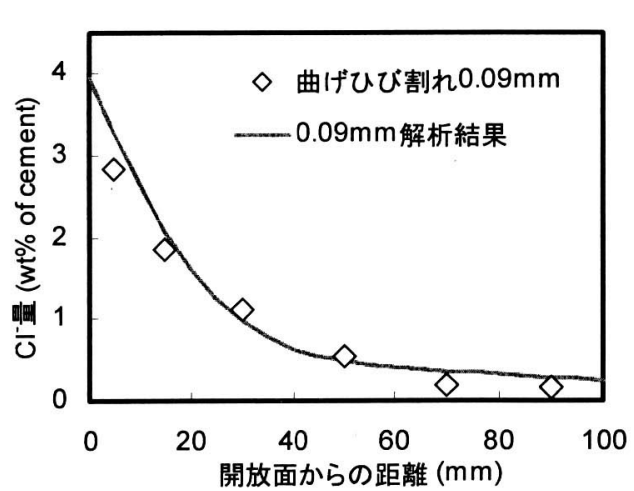

図- 21 ひび割れ部 $\mathrm{Cl}^{-}$量（W/C $=0.60$ 乾湿 13 週）

び割れ部およびその周辺（約 $70 \times 100 \mathrm{~mm} ）$ のコンク リート中の $\mathrm{Cl}^{-}$量を測定した.

\section{b) 解析条件}

促進試験 4 週および 13 週における表面塩分量お

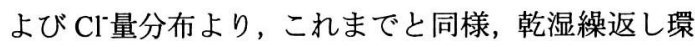
境における表面塩分量の経時変化式 (式(9)), 収束 塩分量と雰囲気濃度の関係式 (式(10)), および $\mathrm{Cl}^{-}$ 拡散係数 $\left(D_{c o n}=3.36 \times 10^{-7} \mathrm{~cm}^{2} / \mathrm{sec}\right)$ を求めた。

$$
\begin{aligned}
C_{0}(t) & =3.98 \cdot\{1-\exp (0.050 t)\} \\
C^{*} & =\left(C_{c r}\right)^{1 / 2} \cdot 2.95
\end{aligned}
$$

ここで,この試験体については, 湿潤時の Cl-移動 性状を把握していない. したがって，3 章において 得られた $\mathrm{W} / \mathrm{C}=0.39$ および 0.55 の湿潤環境下の $\mathrm{Cl}^{-}$ 拡散係数を用いて, W/C $=0.60$ の場合の湿潤時 $\mathrm{Cl}^{-}$拡 散係数, および表面塩分量式における倸数 $a$ および $b$ を概算した. 各係数の予測方法と結果を図- 20 に 示す. 求める係数は全てコンクリートの内部構造に 依存する係数と考えられるため, 全てが W/Cによっ て定まると仮定し，この予測方法を採用した.

このケースの場合, コンクリートの乾湿繰返しサ イクルが (湿潤 4 日十乾燥 3 日) $=7$ 日間であるため, まず 4 日間の湿潤環境下における $\mathrm{Cl}^{-}$移動計算を行う. これより,ひび割れ中の平均 $\mathrm{Cl}$ 濃度を求め, 乾湿繰 返し環境（7 日間）の移動解析を行った。このとき の Cl拡散係数および境界条件は, 乾湿繰返し環境下 における実験結果である.

\section{c) 解析結果}

ひび割れ幅 $0.09 \mathrm{~mm}$ の試験体を対象としたひび割 れ部 $\mathrm{Cl}^{-}$量の解析結果を, 実験結果とともに図- 21 に 示す.また, 図- 22 に, 実験および解析より得られ

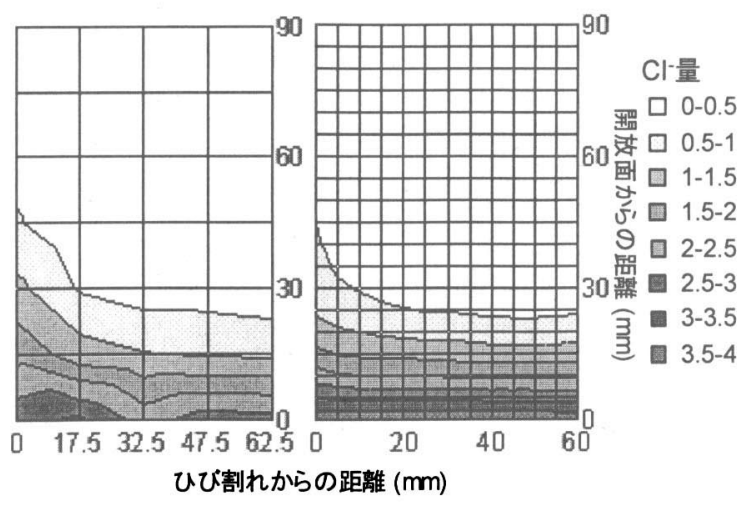

図- $22 \mathrm{Cl}^{-}$量分布 $(\mathrm{W} / \mathrm{C}=0.60$ 乾湿 13 週 $)$

たひび割れ周辺部の $\mathrm{Cl}^{-}$量分布を示す. 解析結果は,

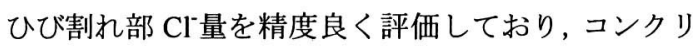
一ト内奥部に至るまで実験結果を度良く再現してい ることが分かる.

以上より，湿潤環境下を概算したにも関わらず， 本手法により乾湿繰返し環境下におけるコンクリー

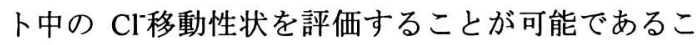
とが示された.

\section{6. まとめ}

本研究で得られた成果を以下にまとめる.

1) $3.0 \% \mathrm{NaCl}$ 水溶液への浸漬試験および乾湿繰返 し試験において, コンクリートひび割れ部および

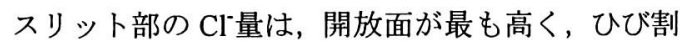
れ梁さが大きくなるにつれて低くなった．この現 象はひび割れ・スリット幅の変化如何によらず生

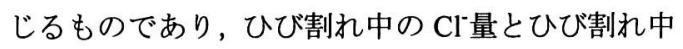
からひび割れ部へ侵入する $\mathrm{Cl}^{-} の$ 移動量の大小関 係によって生じるものと考えられる.

2) コンクリートひび割れ部を開放面と同様に取扱

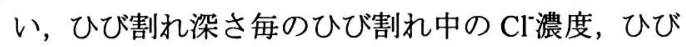
割れ部の $\mathrm{Cl}^{-}$量, および $\mathrm{Cl}^{-}$量に対する質量保存則 を考慮することにより，コンクリート中における 濃度拡散と擬似吸着をマク口的に表現した $\mathrm{Cl}^{-}$移 動評価モデルを構築した。

3) 提案モデルは, 湿潤および乾湿繰返し環境下に おけるひび割れを有するコンクリートの $\mathrm{Cl}^{-}$移動 性状を概ね再現することができた，精度の良い推 定のためには, 表面塩分量の経時変化式の設定が 重要である.

4） $\mathrm{Cl}^{-}$供給量を決定するひび割れ幅と， $\mathrm{Cl}^{\text {消費量を }}$ 
決定するコンクリートの $\mathrm{Cl}^{-}$拡散係数のバランス により,ひび割れ部の $\mathrm{Cl}^{-9}$ 量は決定される.そして, 【供給量く消費量】の条件下において，ひび割れ

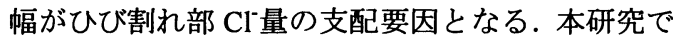
は,ひび割れ幅 $0.075 \mathrm{~mm}$ 末満においてこの条件を 満足する.

5）提案モデルを乾湿繰返し環境下に適用するには, 乾湿繰返し環境下における表面塩分量および拡散 係数だけでなく, 同じ配合条件のコンクリートの 湿潤環境下における表面塩分量, および拡散係数 を把握,或いは予測することが必要である．但し， その環境を乾湿サイクルとして表せることが解析 モデルの適用条件である.

本研究では，表面塩分量を式(2)により，雾囲気濃 度と表面塩分量の関係を式(3)の様に表現し，これを 用いてコンクリート中の Cl'移動評価を行った. コン クリートの配合条件および環境条件と, 収束塩分量 $C^{*}$, または係数 $a, b$, および見かけの拡散係数の関 係を，詳細に検討し定式化することができれば，本 モデルはより汎用性を持ち, 塩分環境下におけるひ び割れを有するコンクリートの $\mathrm{Cl}$ 移動性状の精度 良い推定が可能となると考えられる.

謝辞 : 本研究は東京大学生産技術研究所魚本研究室 にて行われた. 本研究を行うにあたりご協力いただ いた芝浦工業大学 矢島哲司教授, 同大学 勝木太助 教授, 東京大学生産技術研究所 星野富夫氏, 魚本研 究室の皆様に梁く感謝いたします．また，本研究の 一部は平成 13 年度吉田研究奨励金により行われた ことを付記しここに謝意を表します。

\section{参考文献}

1) 例えば 大即 信明, 宮里 心一, 柴田 常徳, 久田 真, Tarek Uddin Md., 長瀧 重義 : 鉄筋コンクリートの曲
げひび割れ部に生じる腐食の形態機構に及ぼす水セ メント比の影響, 土木学会論文集, No.606/V - 31, pp.63 $-73,1998.11$.

2) 岡田 清, 小柳 洽, 宮川 豊章: コンクリート部材の ひび割れと鉄筋腐食に関する研究，土木学会論文集, No.281, pp.75-87, 1979.

3）日本コンクリート工学協会: コンクリート構造物の腐 食・防食に関する試験方法ならびに基隻（案）, 1987.

4）後藤 幸正, 大塚 浩司: 引張りを受ける異形鉄筋周辺 のコンクリートに発生するひび割れに関する実験的 研究, 土木学会論文報告集, 第 294 号, pp.85-108, 1980.2 .

5) 伊代田 岳史, 矢島 哲司, 魚本 健人：コンクリート のひび割れが塩分の浸透深さに及ぼす影響,土木学会 年次学術講演会講演概要集 V, Vol.53, pp.210-211, 1998.

6) 丸屋 剛 : コンクリート中の塩化物イオンの移動に関 する解析手法の構築, 東京大学学位論文, 1995.

7) Buenfeld, N. R. and Newman, J. B. : The Permeability of Concrete in Marine Environment, Magazine of Concrete Research, Vol.36, No.127, pp.67-80, 1984.

8) 枅田 佳寛, 友沢 史紀, 安田 正雪, 原 謙治: コンク リート中への塩化物浸透速度に関する実験, コンクリ 一ト工学年次論文報告集, Vol.10, No.2, pp.493-498, 1988.

9）竹田 祐二, 妌田 佳寛, 中村 茂春, 吉瀬 健二: セメ ントペーストの塩化物イオン浸透メカニズムに関す る実験, コンクリート工学年次論文報告集, Vol.23, No.2, pp.505-510, 2001.

10) Crank, J. : The Mathematics of Diffusion Second Edition, Oxford Science Publications, 1995.

11）濱田 秀則, Swamy, R.N. : 種々の海洋環境下における コンクリート中への塩化物イオンの侵入過程および 侵入量に関する一考察, コンクリート工学論文集, Vol.7, No.1, pp.369-374, 1996.

(2002.5.24 受付)

\title{
A STUDY ON THE EVALUATION METHOD OF CHLORIDE ION MOVEMENT IN CRACKED CONCRETE
}

\author{
Ema TSUKAHARA, Yoshitaka KATO and Taketo UOMOTO
}

\begin{abstract}
This paper aims to develop the evaluation method of chloride penetration in cracked concrete. The method is based on a simple apparent diffusion theory of chloride through concrete, enabling the prediction by obtaining the data at periodic inspection. Considering the chloride distribution in crack and mass preservation rule of chloride ion and applying different boundary chloride conditions to cracked portion and other surface, chloride penetration in cracked concrete can be predicted numerically in case of the wetting condition and cyclic wetting and drying condition. And effects of crack widths and apparent diffusion coefficient inside crack can be evaluated numerically.
\end{abstract}

